\title{
A Map of Specific Cleavage Sites and tRNA Genes in the Chloroplast Genome of Euglena gracilis bacillaris
}

\author{
M. Raafat El-Gewely ${ }^{1}$, Margaret I. Lomax ${ }^{1}$, Elizabeth T. Lau ${ }^{1}$, Robert B. Helling ${ }^{1}$, \\ William Farmerie ${ }^{2}$, and W. Edgar Barnett ${ }^{2}$ \\ 1 Division of Biological Sciences, University of Michigan, Ann Arbor, Michigan 48109, USA \\ 2 Division of Biology, Oak Ridge National Laboratory, Oak Ridge, Tennessee 37830, USA
}

Summary. A map showing locations of 22 of the 30 endonuclease EcoRI cleavage sites and 54 additional sites for eight other restriction endonucleases is presented. The regions of chloroplast DNA that hybridize with chloroplast tRNA are also shown.

\section{Introduction}

Chloroplasts and mitochondria are self-duplicating, arising only by growth and division of pre-existing chloroplasts and mitochondria. These organelles contain unique genetic information, as revealed most simply by the demonstration that specific mutant genes can be located within them (Birky, Jr. 1978). Although chloroplasts and mitochondria may be considered genetically autonomous, obeying their own unique rules of inheritance, functionally they are not autonomous. For example, each contains a protein synthesizing apparatus dependent on RNA transcribed from organellar genes, but most ribosomal proteins are encoded in nuclear genes. In their reliance on the host genome, organelles are similar to viruses or other obligate intracellular parasites.

Our interest in understanding the organization, structures, and functions of organellar genes has focused on the chloroplast of the unicellular alga Euglena gracilis. These chloroplasts contain multiple copies of circular DNA molecules (clDNA) about 130-140 kilobase pairs (kb) in circumference (Manning and Richards 1972; Slavic and Hershberger 1975). Each clDNA molecule contains three complete sets of genes for ribosomal RNA (rRNA; Rawson et al. 1978; Gray and Hallick 1978; Kopecka et al. 1977; Helling et al. 1979) and approximately 24-30 transfer RNA (tRNA) genes (Schwartzbach et al. 1976; McCrea and Hershberger 1976; Gruol and Haselkorn 1976; Mubumbila et al. 1980). The overall organization of the rRNA genes (rDNA) in the two commonly studied laboratory strains, B (bacillaris) and $\mathrm{Z}$, is similar, although differences in the rDNA leader sequences have been demonstrated (Helling et al. 1979). In addition a part of a fourth rRNA gene set has been identified in strain Z (Jenni and Stutz 1979). After subtracting the rRNA and tRNA genes, sufficient DNA remains to code for over 100 polypeptides of 25,000 daltons molecular weight.

We would like to achieve a complete map of the chloroplast genes of $E$. gracilis bacillaris, and an understanding of how these genes are regulated. In order to provide a framework within which we can place all other genes we have developed a clDNA map showing 76 restriction endonuclease cleavage sites, and the locations of the tRNA and rRNA genes.

For offprint contact: M.R. El-Gewely

\section{Materials and Methods}

Strains. All plasmids were maintained in Escherichia coli $\mathrm{K} 12$ strain RH202 ( $\mathrm{F}^{-}$thi lac Y tonA supE44 hss) (Adams et al. 1979). E. gracilis bacillaris chloroplast DNA isolation was essentially as described (Lo$\max$ et al. 1977).

Plasmids. Recombinant plasmids containing chloroplast DNA fragments were constructed as described (Lomax et al. 1977; Helling and Lomax 1978; Helling et al. 1979). All plasmids were purified by transformation prior to DNA isolation. Plasmid DNA preparations were prepared as described (El-Gewely and Helling 1980). A list of the plasmids used in this study is presented in Table 1. Cloned fragments were released from the cloning vehicle by digestion with the appropriate restriction endonuclease, and the fragments were purified by rate-zonal sedimentation (El-Gewely and Helling 1980).

Restriction Endonucleases. The enzymes AvaI, BalI, BamHI, BgllI, EcoRI, HindIII, Hpal, HpaII, KpnI, PstI, PvuII, Sa1I, TaqI, XhoI were purchased from New England Biolabs and/or Bethesda Research Labs and used as indicated on the instruction sheet. They are referred to as Ava, Bal, Bam, Bgl, Eco, Hin, HpaI, HpaII, Kpn, Pst, Pvu, Sal, Taq, and Xho in this paper.

Table 1. Recombinant plasmids containing chloroplast DNA

\begin{tabular}{|c|c|c|c|}
\hline Plasmid & $\begin{array}{l}\text { Cloned chloroplast } \\
\text { DNA fragment }\end{array}$ & $\begin{array}{l}\text { Size of } \\
\text { fragments }(\mathrm{kb})\end{array}$ & $\begin{array}{l}\text { Parent } \\
\text { plasmid }\end{array}$ \\
\hline \multirow{15}{*}{ pMIL } & Eco L & 3.30 & RSF2124 \\
\hline & Eco R & 2.495 & RSF2124 \\
\hline & $E \operatorname{co} R+V+2 A / 2 B^{a}$ & $2.49+1.34+0.92$ & RSF2124 \\
\hline & $\mathrm{E} \operatorname{co} 2 \mathrm{~A} / 2 \mathrm{~B}^{\mathrm{a}}$ & 0.92 & RSF2124 \\
\hline & $\mathrm{E} \cos +\mathrm{U}+2 \mathrm{~A}$ & $2.30+1.69+0.92$ & RSF2124 \\
\hline & Eco $M$ & 3.20 & RSF2124 \\
\hline & Eco $V+X$ & $1.34+1.11$ & RSF2124 \\
\hline & $E c o J+R$ & $3.65+2.495$ & RSF2124 \\
\hline & Eco P & 2.95 & RSF2124 \\
\hline & Eco X & 1.11 & RSF2124 \\
\hline & Eco I & 4.65 & RSF2124 \\
\hline & $\mathrm{Eco} 2 \mathrm{~A} / 2 \mathrm{~B}^{\mathrm{a}}$ & 0.92 & RSF2124 \\
\hline & $\begin{array}{l}\text { Eco } 2 \mathrm{~A} / 2 \mathrm{~B}^{\mathrm{a}}+2 \mathrm{C} \\
(2 \text { copies })\end{array}$ & $0.92+2 \times 0.87$ & RSF2124 \\
\hline & Eco T & 1.77 & RSF2124 \\
\hline & $\mathrm{Eco} \mathrm{N}+\mathrm{O}$ & $3.05+2.95$ & RSF2124 \\
\hline pRBH 021 & Sal C & 4.40 & pBR322 \\
\hline 022 & Bam F & 5.25 & pBR322 \\
\hline 026 & Bam E & 5.68 & pBR322 \\
\hline 044 & Eco P & 2.95 & RSF2124 \\
\hline
\end{tabular}

a Fragment is either $2 \mathrm{~A}$ or $2 \mathrm{~B}$ as judged by size 
Electrophoresis. Fractionation and size estimation of endonucleasegenerated DNA fragments was achieved by agarose gel electrophoresis (Helling et al. 1974, 1979). Agarose concentration varied from 0.6 to $1.9 \%$ depending on the size of the fragments. P22-Eco fragments and/or pBR322-Taq fragments were used as DNA size standards.

Transfer of DNA to Nitrocellulose Membranes. Separated DNA fragments in agarose gels were photographically recorded, then denatured an transferred to nitrocellulose membranes (Southern 1975) essentially as described in Helling et al. 1979.

Preparation of ${ }^{125} I-t R N A$. The $\mathrm{tRNA}$ was purified from isolated chloroplasts of $E$. gracilis bacillaris, and iodinated as described (Schwartzbach et al. 1976).

DNA/tRNA Hybridization. The dried filters containing denatured DNA fragments were incubated with the Denhardt mixture (Denhardt 1966) for $2-4 \mathrm{~h}$ at $65^{\circ} \mathrm{C}$, in heat sealed freezing bags. Although RNA was reported not to bind to nitrocellulose membranes (Gillespie and Spiegelman 1965), the prehybridization treatment was found to be essential to reduce non-specific binding of tRNA and thus reduce the background. Prolonged incubation resulted in loss of DNA from the filters. Hybridization was made in the same bags, after decanting the prehybridization medium, for $16-24 \mathrm{~h}$ at $33^{\circ} \mathrm{C}$. The hybridization mixture (pH 5.2) contained ${ }^{125} \mathrm{I}$-tRNA $(23 \mu \mathrm{g} / \mathrm{ml}$; specific activity about $\left.2 \times 10^{6} \mathrm{cpm} / \mu \mathrm{g}\right)$, unlabelled chloroplast rRNA $(184690 \mu \mathrm{g} / \mathrm{ml})$, bovine serum albumin $(20 \mu \mathrm{g} / \mathrm{ml}), 2 \times \mathrm{SSC}, 0.05 \mathrm{M}$ ammonium acetate and $33 \%$ formamide. (SSC is $0.15 \mathrm{M} \mathrm{NaCl}-0.015 \mathrm{M}$ sodium citrate, $\mathrm{pH} 7.0$ ). After hybridization the filters were incubated with $2 \times \mathrm{SSC}$,
$0.05 \mathrm{M}$ ammonium acetate, $33 \%$ formamide ( $\mathrm{pH} 5.2$ ) for $20 \mathrm{~min}$ at $33^{\circ} \mathrm{C}$, then washed 3 times with $2 \times \mathrm{SSC}, 0.05 \mathrm{M}$ ammonium acetate $\mathrm{pH}$ 5.2. Filters were incubated at room temperature for $30 \mathrm{~min}$ with preboiled RNase A (Sigma Type $1 \mathrm{~A})(20 \mu \mathrm{g} / \mathrm{ml})$ in $2 \times \mathrm{SSC}, 0.05 \mathrm{M}$ ammonium acetate pH 5.2, and washed in the same buffer 3 times and dried in a vacuum oven at $75^{\circ}$ for $2 \mathrm{~h}$. Bands were visualized by fluorography with intensifying screens at $-70^{\circ}$ (Swanstrom and Shank, 1978) and Kodak XR-5 film. Exposure was for one to six days.

\section{Results}

The Products of Restriction Endonuclease Digestion of Chloroplast $D N A$. Purified chloroplast DNA from E. gracilis bacillaris was treated with ten restriction enzymes (separately) and each digest was subjected to agarose gel electrophoresis. The number and sizes of fragments generated by each nuclease were determined, as shown in Tables 2 and 3. Sma did not cleave cIDNA, in agreement with data on c1DNA from strain Z (Kopecka, Crouse and Stutz, 1977; Gray and Hallick, 1978). Sma and Xho recognition sequences belong to the family of nucleotide sequences cut by Ava (Table 3). Ava sites in cloned segments of the rDNA that are not cut by Xho are also not cut by Sma, even though Sma cuts $\lambda$ DNA made in the same strain of $E$. coli (not shown). Lack of cleavage of c1DNA by Sma probably reflects lack of any CCCGGG sequence, rather than modification of the Sma recognition site of DNA in the chloroplast.

Table 2. Sizes of cIDNA fragments generated by enzyme (in base pairs) ${ }^{a}$

\begin{tabular}{|c|c|c|c|c|c|c|c|c|c|}
\hline \multirow[t]{2}{*}{ Fragment } & \multicolumn{9}{|l|}{ Enzyme } \\
\hline & EcoRI & Ava I & Bal I & Xho I & BamHI & Pvu II & Pst I & Kpn I & Sal I \\
\hline $\mathrm{A}$ & 21340 & 41580 & 37345 & 47835 & 57350 & 67510 & 52435 & 73005 & 86675 \\
\hline B & 19610 & 26695 & 26440 & 41580 & 45195 & 25850 & 36790 & 50050 & 42925 \\
\hline $\mathrm{C}$ & 9700 & 12070 & 17345 & 29495 & 14830 & 21300 & 26065 & 5695 & 4400 \\
\hline D & 9090 & 10690 & 12480 & 5680 & 5695 & 8800 & 11660 & 5250 & \\
\hline $\mathrm{E}$ & 7400 & 10680 & 10300 & 5250 & 5680 & 6850 & 7050 & & \\
\hline F & 7300 & 7700 & 7360 & 3550 & 5250 & 3690 & & & \\
\hline $\mathrm{G}$ & 7000 & 3850 & 6500 & 610 & & & & & \\
\hline $\mathrm{H}$ & 5300 & 3450 & 5680 & & & & & & \\
\hline I & 4650 & 2800 & 5250 & & & & & & \\
\hline J & 3650 & 2800 & 2900 & & & & & & \\
\hline K & 3650 & 2750 & 2400 & & & & & & \\
\hline L & 3300 & 2130 & & & & & & & \\
\hline M & 3200 & 2115 & & & & & & & \\
\hline $\mathrm{N}$ & 3050 & 1685 & & & & & & & \\
\hline $\mathrm{O}$ & 2950 & 765 & & & & & & & \\
\hline $\mathrm{P}$ & 2950 & 765 & & & & & & & \\
\hline$Q$ & 2570 & 765 & & & & & & & \\
\hline $\mathrm{R}$ & 2495 & 610 & & & & & & & \\
\hline S & 2300 & 100 & & & & & & & \\
\hline $\mathrm{T}$ & 1770 & & & & & & & & \\
\hline $\mathrm{U}$ & 1690 & & & & & & & & \\
\hline V & 1340 & & & & & & & & \\
\hline W & 1130 & & & & & & & & \\
\hline $\mathrm{X}$ & 1130 & & & & & & & & \\
\hline Y & 1120 & & & & & & & & \\
\hline $\mathrm{Z}$ & 950 & & & & & & & & \\
\hline $2 \mathrm{~A}$ & 920 & & & & & & & & \\
\hline $2 \mathrm{~B}$ & 920 & & & & & & & & \\
\hline $2 \mathrm{C}$ & 870 & & & & & & & & \\
\hline $2 \mathrm{D}$ & 430 & & & & & & & & \\
\hline
\end{tabular}

a Fragments below about 200 base pairs would not have been detected. Sizes of fragments larger than $12 \mathrm{~kb}$ were estimated by adding component segments generated by cutting with other restriction nucleases (see text), and setting total clDNA size at $134 \mathrm{~kb}$ 
Table 3. Predicted and observed numbers of restriction endonuclease cleavage sites in clDNA.

\begin{tabular}{|c|c|c|c|c|c|}
\hline \multirow[t]{2}{*}{ Enzyme } & \multirow[t]{2}{*}{$\begin{array}{l}\text { Recognition } \\
\text { Sequence }\end{array}$} & \multicolumn{2}{|c|}{$\begin{array}{l}\text { No. of cleavage } \\
\text { sites expected }\end{array}$} & \multicolumn{2}{|c|}{$\begin{array}{l}\text { No. of cleavage } \\
\text { sites observed }^{b}\end{array}$} \\
\hline & & total & $\begin{array}{l}\text {-repeated } \\
\text { rDNA }^{c}\end{array}$ & total & $\begin{array}{l}\text {-repeated } \\
\text { sites }^{c}\end{array}$ \\
\hline Sma I & $\mathrm{CCC} \downarrow \mathrm{GGG}$ & 0.5 & 0.5 & 0 & 0 \\
\hline Sal I & $\mathrm{G} \downarrow$ TCGAC & 4.6 & 4.3 & 3 & 3 \\
\hline Kpn I & GGTAC $\downarrow C$ & 4.6 & 4.3 & 4 & 2 \\
\hline Pst I & CTGCA $\downarrow$ G & 4.6 & 4.3 & 5 & 5 \\
\hline BamH I & $\mathrm{G} \downarrow \mathrm{GATCC}$ & 4.6 & 4.3 & 6 & 4 \\
\hline Pvu II & $\mathrm{CAG} \downarrow \mathrm{CTG}$ & 4.6 & 4.3 & 6 & 6 \\
\hline Xho I & $\mathrm{C} \downarrow$ TCGAG & 4.6 & 4.3 & 7 & 5 \\
\hline Bal I & $\mathrm{TGG} \downarrow \mathrm{CCA}$ & 4.6 & 4.3 & 11 & 9 \\
\hline Ava I ${ }^{d}$ & $\mathrm{C} \downarrow$ PyCGPuG & 3.0 & 2.8 & 12 & 8 \\
\hline EcoRI & $\mathrm{G} \downarrow$ AATTC & 41.7 & 38.3 & 30 & 26 \\
\hline \multicolumn{2}{|c|}{ Total without EcoRI } & 35.7 & 33.4 & 54 & 42 \\
\hline \multicolumn{2}{|c|}{ Total with EcoRI } & 77.4 & 71.7 & 84 & 68 \\
\hline
\end{tabular}

a Assumes 75\% A+T base composition (Brawerman and Eisenstadt, 1964; Ray and Hanawalt, 1964; Edelman et al., 1964), and a total cIDNA size of $134 \mathrm{~kb}$

b Minimal estimate becouse several adjacent sites might be counted as a single site

- $11 \mathrm{~kb}$ corresponding to two of the three repeated rRNA gene sets, and corresponding restriction sites were subtracted from the entire genome totals to obtain these estimates

d Does not include Xho or Sma sites which are also cleaved by Ava

The thirty Eco fragments sum to almost $134 \mathrm{~kb}$, and so we have assumed a total chloroplast genome size of $134 \mathrm{~kb}$. From the size and base composition of the DNA, and the specificity of each restriction endonuclease, the number of cleavage sites per cIDNA molecule can be predicted (Table 3). In most cases the observed number of sites agrees with the predicted number, especially when the repeated rRNA genes are not considered (Table 3).

Mapping Restriction Sites in c1DNA by Digestion with Two or More Restriction Enzymes. We have previously mapped two of the three Sal sites, nine Eco sites, and associated rRNA genes (Helling et al. 1979). Figure 1 shows that Sal cleaves Eco fragments B, E, and G. Furthermore the two Sal cleavage products of each Eco fragment can be identified. Similar double-digest patterns of c1DNA have been used to determine the positions of other restriction sites. (Figs. 2, 7, 8, 9, 10, Tables 4-6). Although every double digest contained some fragments that were too large to estimate precisely, the use of many combinations allowed precise distance estimates to be made over most of the chloroplast chromosome (i.e., based on digestion products of 0.6 to $5 \mathrm{~kb}$ ).

The three Sal segments of c1DNA could be oriented (going clockwise from the origin) as Sal C-Sal A - Sal B, or as Sal CSal B-Sal A. (The map origin was defined by the Sal C fragment; Helling et al. 1979). The following results show the former order to be correct. Sal cleaves Bam $\mathrm{C}$ into two new fragments whose combined lengths $(2.71 \mathrm{~kb}$ and approximately $12 \mathrm{~kb}$; Table 5) equal that of Bam $C$ (about $14.8 \mathrm{~kb}$ ). The distance from the Sal site at the map origin counterclockwise until about $12 \mathrm{~kb}$ past the last Bam site in the rDNA repeat region corresponds to the estimated size of Sal B. Bam B must extend across the map origin because it was also cleaved by Sal. If the alternative order Sal C-Sal B-Sal A were correct, then the Bam fragments

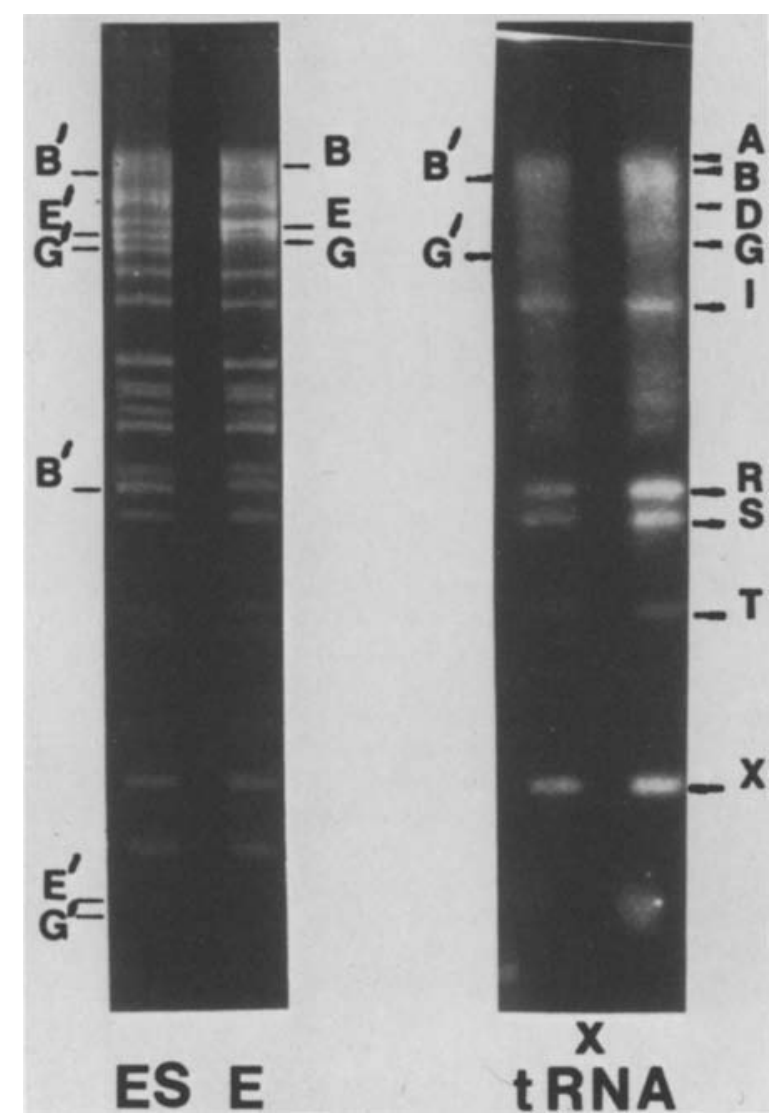

Fig. 1. Chloroplast tRNA hybridization with cIDNA digested by Eco (E) and by Eco + Sal (ES). Left: DNA fragment pattern after agarosegel electrophoresis. Eco fragments before and after cleavage by Sal are designated. Right: Corresponding hybridization patterns with tRNA. Hybridizing Eco fragments, and hybridizing derivatives of Eco $B$ and Eco $G$ after Sal cleavage are identified

would necessarily be ordered as $\mathrm{B}-\mathrm{C}-\mathrm{A}-\mathrm{D}-\mathrm{E}-\mathrm{F}$ (instead of the correct order $B-A-C-D-E-F)$, the termini of Sal B falling within Bam B and Bam C. However the sizes of the SalBam digest products do not agree with those expected of this alternative arrangement. All of our results agree with the order: Sal C-A $-\mathrm{B}$, and Bam B-A $-\mathrm{C}-\mathrm{D}-\mathrm{F}-\mathrm{E}$.

With pairs of enzymes producing few fragments, the cleavage patterns are generally simple (as shown in Fig. 2 for $\mathrm{Bal}+\mathrm{Kpn}$ and $\mathrm{Bal}+\mathrm{Xho}$ ). Kpn cuts clDNA four times; three sites have already been located within the rDNA (Helling et al. 1979). Kpn cleaves Bal D, G, H, and I (Fig. 2). The Bal fragments $G, H$ and I each correspond to the length of the rDNA repeat (Table 2), and location of those Bal fragments in the rDNA was confirmed by hybridization with rRNA and cleavage of cloned rDNA segments (not shown). Similar double-digest experiments showed that the fourth $\mathrm{Kpn}$ site is in fragments Ava A, Bam A or B, Eco A, Pru E, Sal A, and Xho A or B. Bal D is cleaved only by Pvu and Kpn (Table 4), and Pvu E is cleaved only by Bal and Kpn (Table 4). These results place both Bal D and Pvu E within Ava A, Eco A and Sal A. From the sizes of the derivative fragments, the Kpn site and the sites bounding Bal D and Pvu E were located with respect to each other. The Eco-Kpn double-digest pattern of c1DNA showed Kpn splits Eco A into new fragments of approximately $5.7 \mathrm{~kb}$ and $15.6 \mathrm{~kb}$. (All other bands in the gel could be accounted for as Eco fragments not cleaved by Kpn, or as Kpn-Eco fragments from the rRNA genes.) Similar double-digests with Eco + Bal and Eco + 
Table 4. Cleavage products resulting from digestion of cIDNA with Bal and another restriction endonuclease

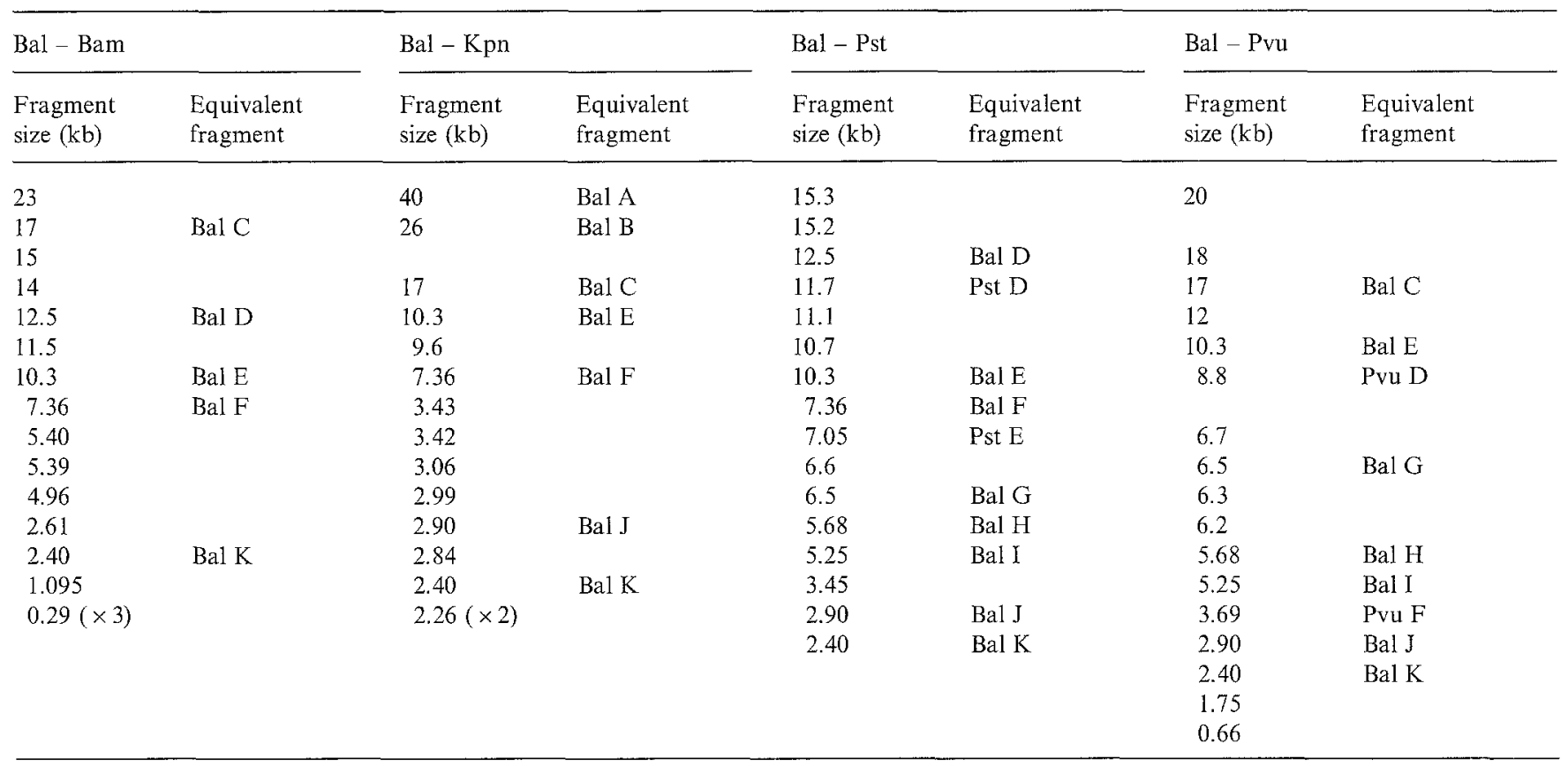

Table 5. Cleavage products resulting from digestion of cIDNA with Bam and another restriction endonuclease

\begin{tabular}{|c|c|c|c|c|c|}
\hline \multicolumn{2}{|l|}{ Bam - Pst } & \multicolumn{2}{|c|}{ Bam - Pvu } & \multicolumn{2}{|l|}{$\mathrm{Bam}-\mathrm{Sal}$} \\
\hline $\begin{array}{l}\text { Fragment } \\
\text { size }(\mathrm{kb})\end{array}$ & $\begin{array}{l}\text { Equivalent } \\
\text { fragment }\end{array}$ & $\begin{array}{l}\text { Fragment } \\
\text { size }(\mathrm{kb})\end{array}$ & $\begin{array}{l}\text { Equivalent } \\
\text { fragment }\end{array}$ & $\begin{array}{l}\text { Fragment } \\
\text { size }(\mathrm{kb})\end{array}$ & $\begin{array}{l}\text { Equivalent } \\
\text { fragment }\end{array}$ \\
\hline 35 & \multirow[t]{3}{*}{ PstB } & 30 & & 60 & \multirow[t]{4}{*}{ Bam A } \\
\hline 25 & & 26 & \multirow[t]{2}{*}{ Pvu B } & 27 & \\
\hline 20 & & 21 & & 14 & \\
\hline 14.8 & $\mathrm{Bam} C$ & 14.8 & Bam $C$ & 12 & \\
\hline 11.7 & Pst D & 8.8 & Pvu D & 5.695 & Bam B \\
\hline 7.05 & Pst E & 6.85 & Pvu E & 5.68 & Bam E \\
\hline 5.695 & Bam D & 5.695 & Bam D & 5.25 & Bam F \\
\hline 5.68 & Bam E & 5.68 & Bam E & 4.40 & Sal C \\
\hline 5.25 & Bam F & 5.25 & Bam F & 2.71 & \\
\hline 1.45 & & 4.05 & & & \\
\hline \multirow[t]{2}{*}{0.40} & & 3.69 & \multirow[t]{2}{*}{ Pvu F } & & \\
\hline & & 0.70 & & & \\
\hline
\end{tabular}

Table 6. Cleavage of Eco fragments of cIDNA by Bam

\begin{tabular}{lc}
\hline Eco fragment $(\mathrm{kb})$ & Products of Bam cleavage $(\mathrm{kb})$ \\
\hline $\mathrm{B}(19.6)$ & $16.5+3.23$ \\
$\mathrm{~F}(7.30)$ & $4.85+2.45$ \\
$\mathrm{H}(5.30)$ & $4.37+0.93$ \\
$\mathrm{~K}(3.65)$ & $3.35+0.3$ \\
$\mathrm{M}(3.20)$ & $2.45+0.75$ \\
$\mathrm{O}(2.95)$ & $2.45+0.50$ \\
\hline
\end{tabular}

Pvu allowed positioning the relevant Bal, Kpn and Pvu sites within Eco fragment A.

The gel patterns revealed most of the Eco fragments that could be cleaved by a second enzyme. For example, Table 6 lists the six Eco fragments that are cleaved by Bam, and the sizes of the derivative fragments. The locations of Bam sites within Eco B, M, and $\mathrm{O}$ were already known (Helling et al. 1979). Of the remaining new Eco-Bam fragments, the $4.85 \mathrm{~kb}$ and $4.37 \mathrm{~kb}$ segments must be associated with Eco $\mathrm{F}$ and Eco $\mathrm{H}$ because each was larger than Eco $\mathrm{K}$. The correct combinations of pairs of double digest products could be determined readily by addition of lengths. We identified the origins of double digest fragments resulting from cleavage with Eco plus Pst, Xho, or Kpn similarly.

We have carried out double-digestions of c1DNA with each possible pair of restriction endonucleases. In several cases triple digests were made in order to confirm mapping assignments. The sum of the data obtained is contained in Tables 2, 4-7, and Fig. 9-10. The use of cloned c1DNA segments, and hybridization with cloned c1DNA or with tRNA simplified our analysis and confirmed our initial mapping as described below.

The Use of Cloned c1DNA Fragments for Mapping. Most of the Eco fragments of clDNA have been cloned in plasmids of E. coli (Table 1; Lomax et al. 1977; Helling et al. 1979). The cloned fragments were used for detailed restriction site mapping. Cleavage patterns of purified Eco fragment $\mathrm{R}$ digested by several 


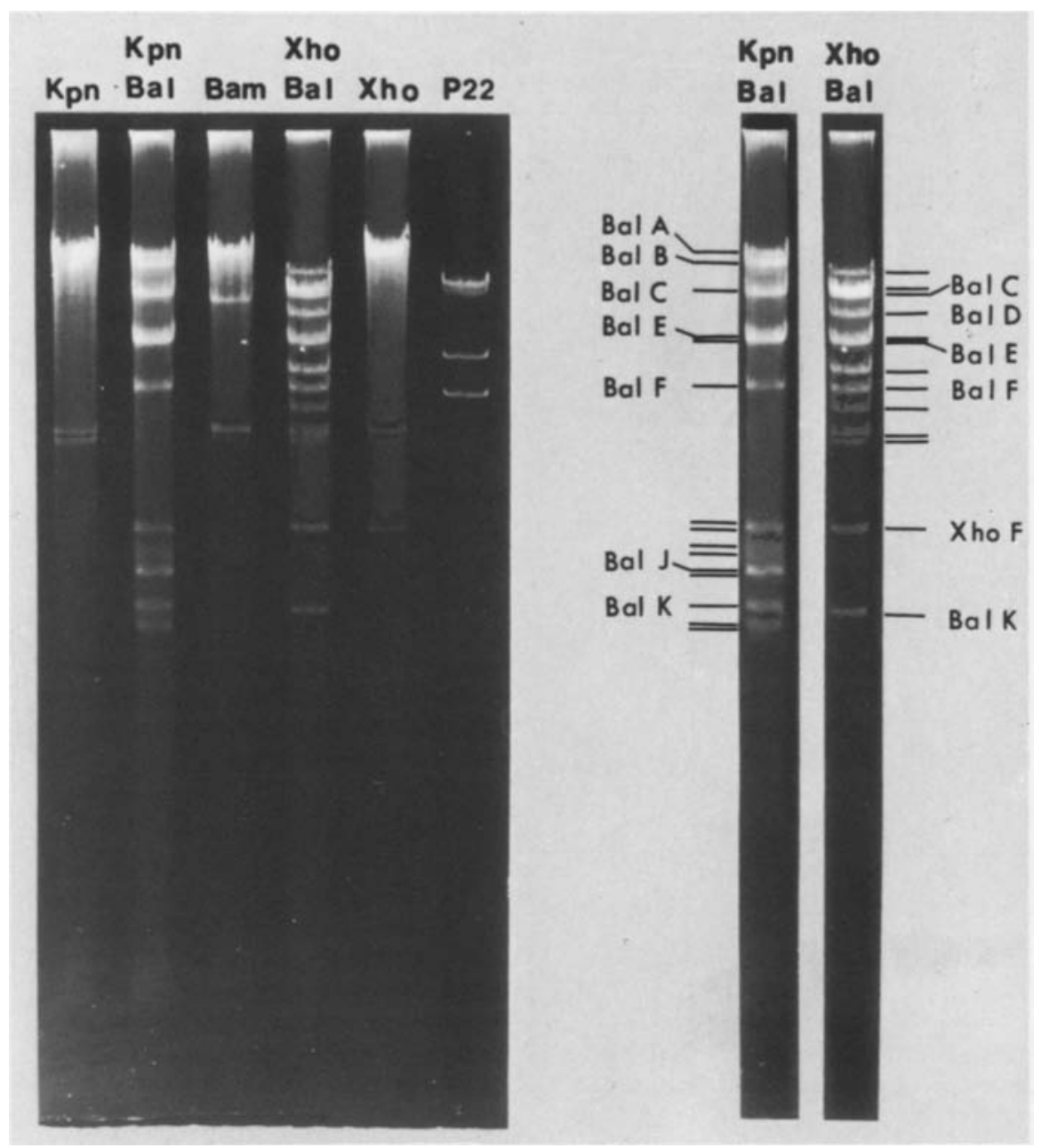

Fig. 2. Agarose gel electrophoresis patterns of cIDNA after cleavage by restriction endonucleases

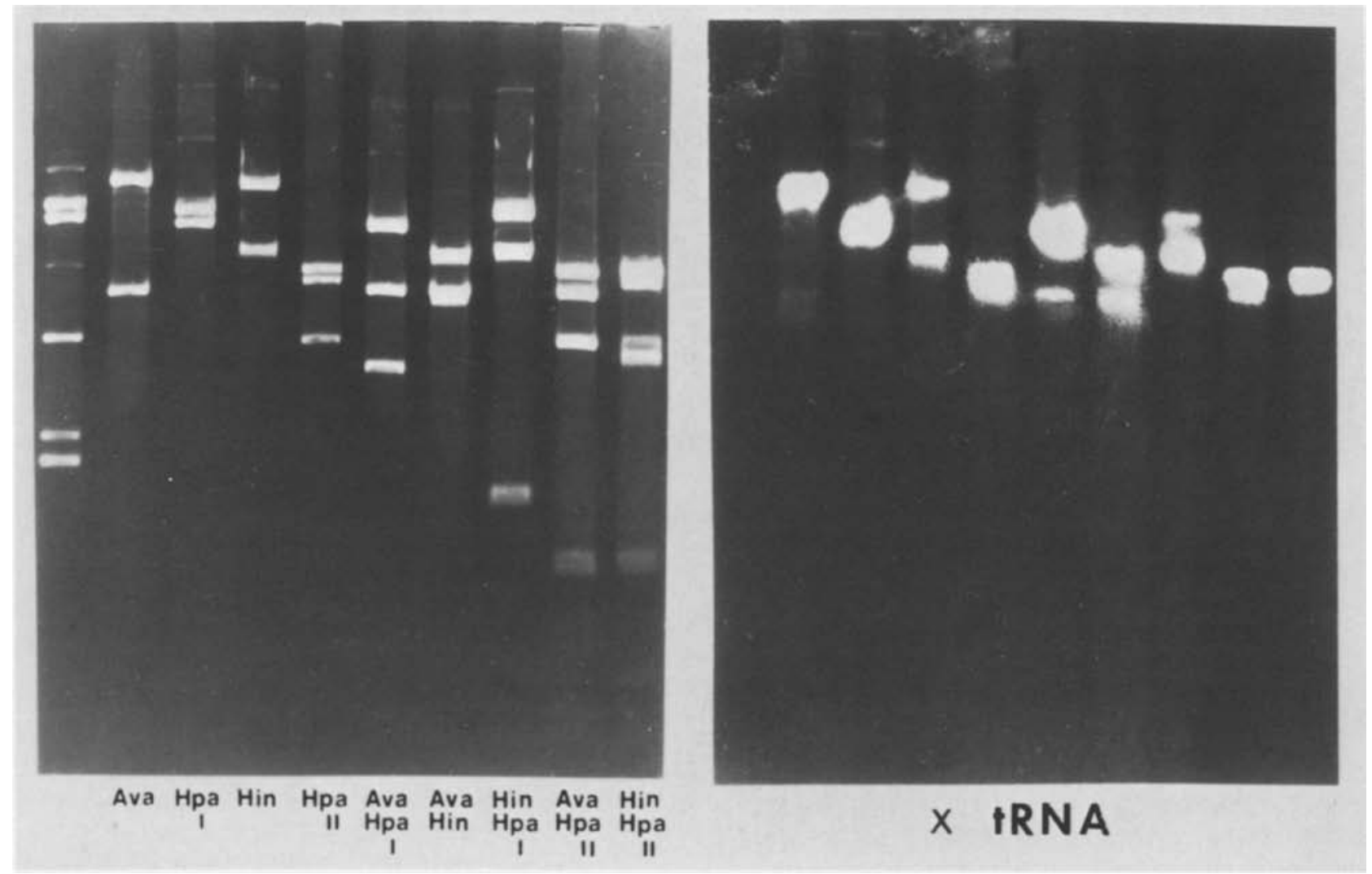

Fig. 3. tRNA hybridization with cloned cIDNA fragment Eco $\mathrm{R}$ after digestion with other endonucleases. Left track in agarose gel (left) shows Taq fragments of pBR322 DNA 


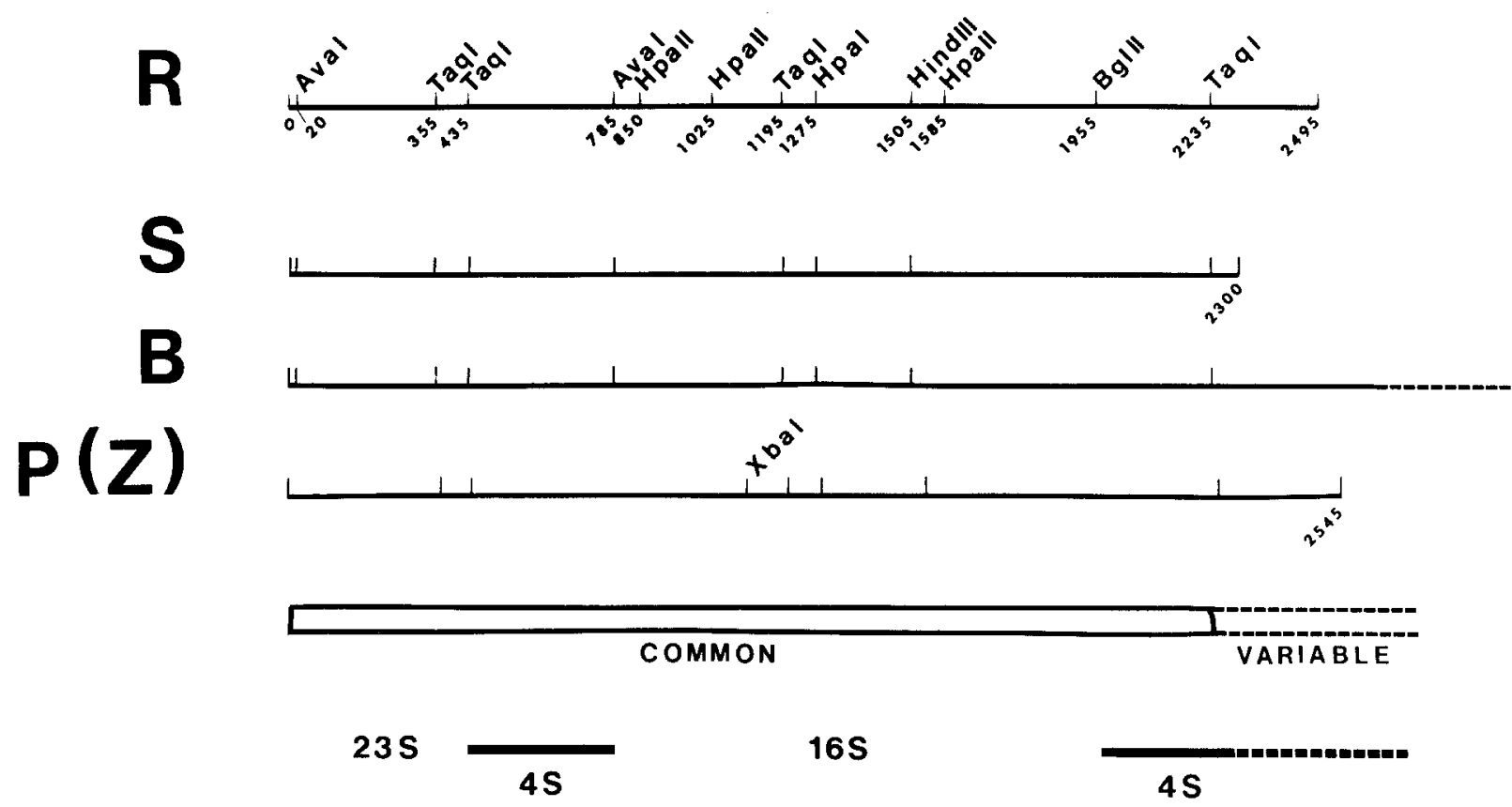

Fig. 4. Restriction site map of proximal portion of the three repeated rRNA gene sets of strain $B$ (Eco fragments R, S, and B) and the equivalent region of strain Z. Segments hybridizing with chloroplast tRNA (Fig. 3) are designated below. Data for strain $Z$ (fragment P) are from Orozco (1979)

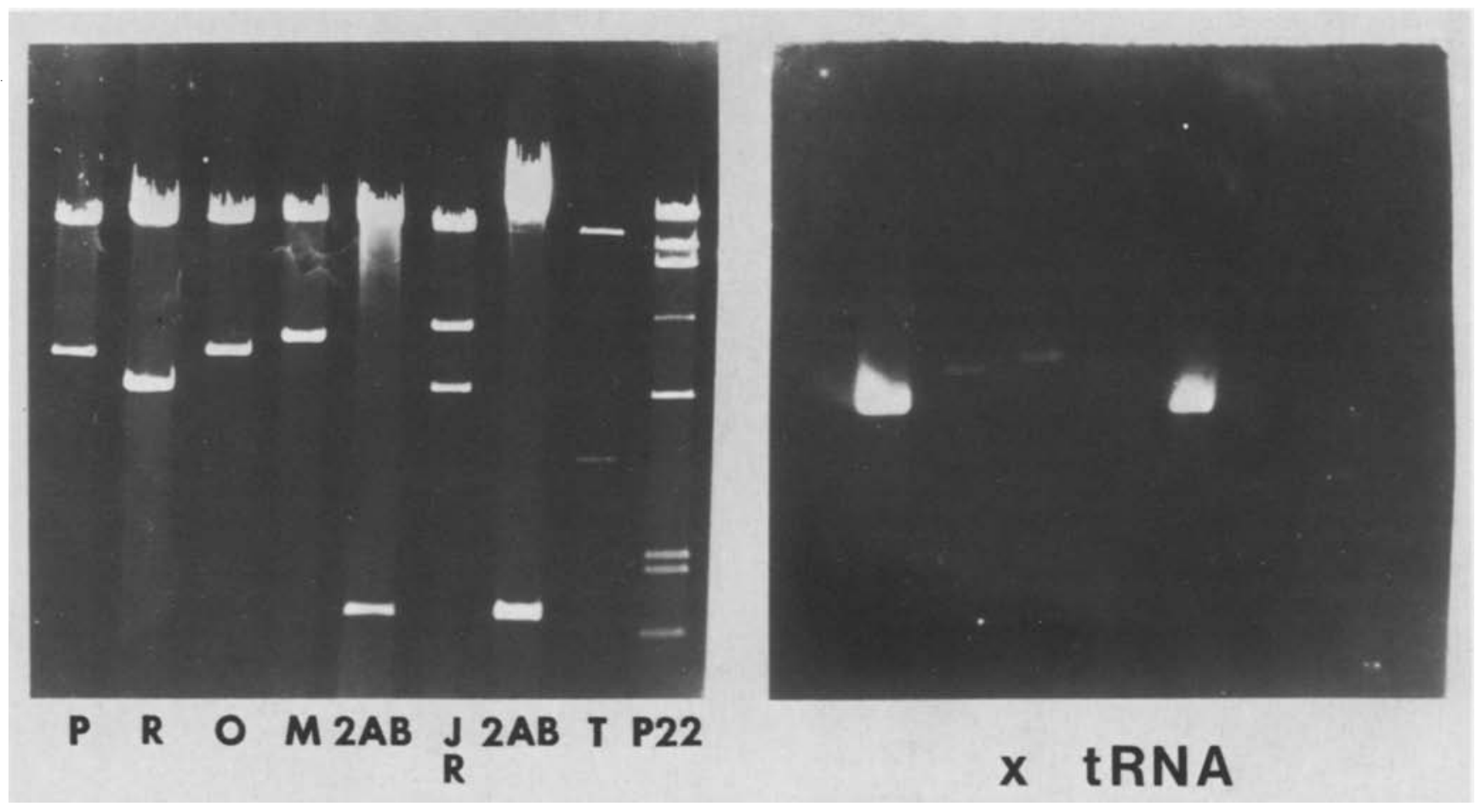

Fig. 5. Hybridization of tRNA with cloned segments of clDNA. Cloned segments are designated. Largest band in each slot except the rightmost corresponds to the pBR322 cloning vehicle. Right slot contains Eco fragments of P22 DNA

restriction endonucleases are shown in Fig. 3. As an example of the way in which this and other data were analyzed to obtain a restriction site map of fragment $R$, consider slots 3 (Hpa 1), 4 (HindIII), and 8 (both enzymes). Each enzyme cut fragment $\mathrm{R}$ once, generating two new fragments. Comparison of the three gel patterns reveals that the Hpa site is within the larger Hin fragment, and the Hin site is within the smaller Hpa fragment. From the sizes of the fragments, a unique restriction site map is readily determined. Detailed maps of fragment $\mathrm{R}$, the homologous region of each of the other rRNA gene repeats, and the equivalent segment from strain $Z$ are shown in Fig. 4 .

Genes for $t R N A .{ }^{125}$ I-labelled tRNA from chloroplasts was used as a hybridization probe with the cloned clDNA segments. Consider the results shown in Fig. 5. The RNA hybridized with Eco fragments $\mathrm{R}$ and $\mathrm{T}$ but not with the plasmid carrier or 


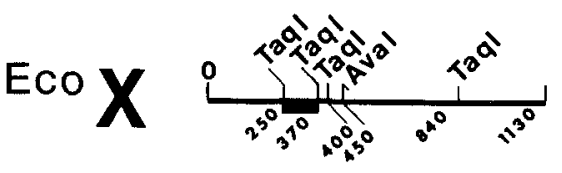

\section{Eco T}
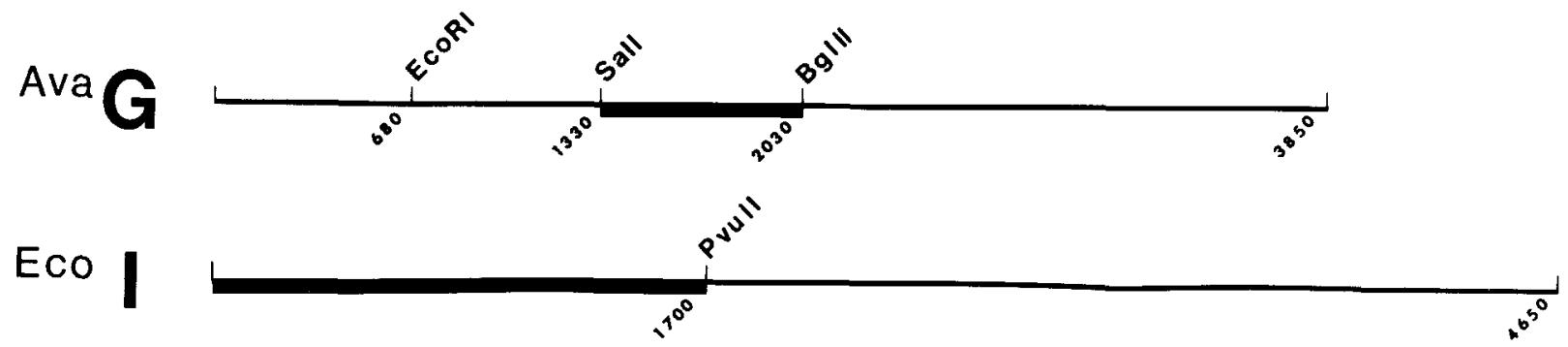

Fig. 6. Regions of tRNA hybridization with cloned fragments of clDNA. tRNA hybridizes with the segments delineated by heavy bars

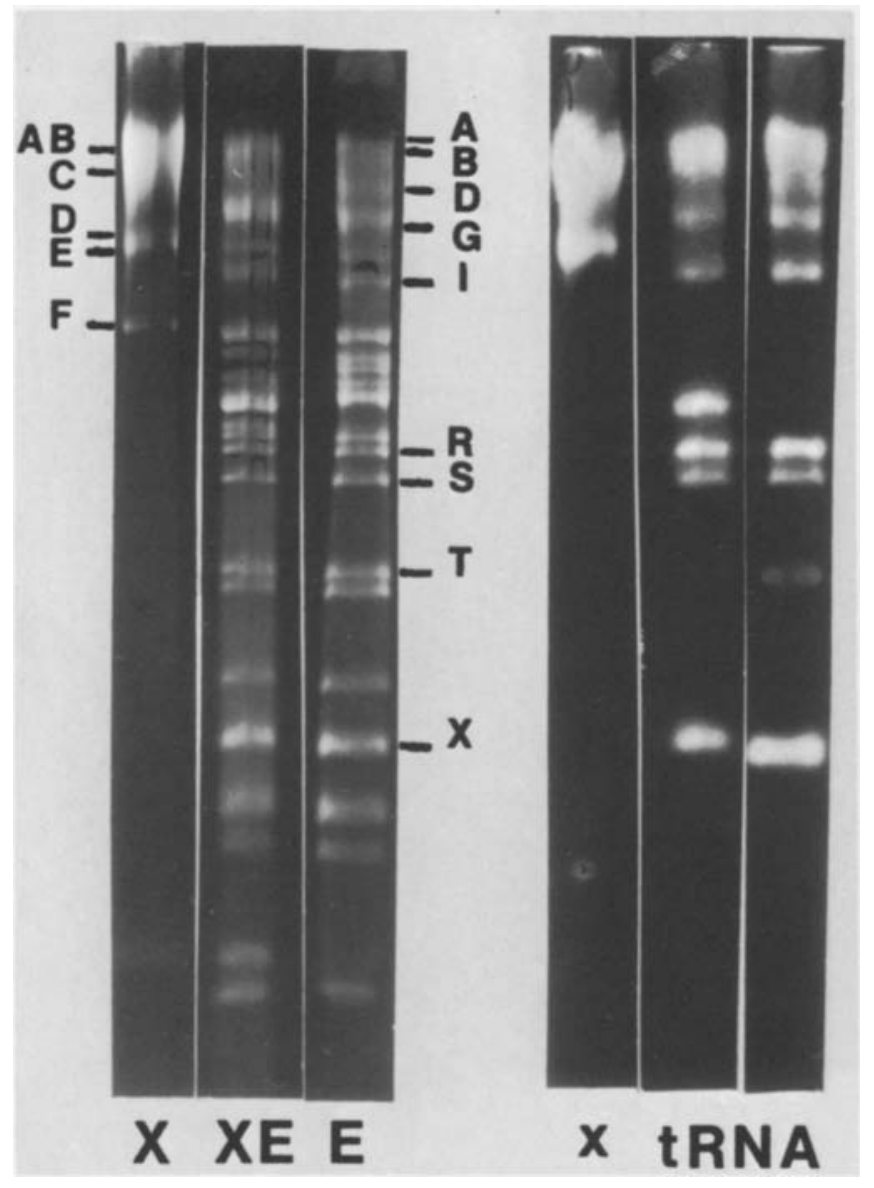

Fig. 7. Chloroplast hybridization with clDNA digested by Xho (X), Eco (E), or Xho+Eco (XE). Left: Separation of clDNA fragments by agarose gel electrophoresis. Xho and Eco fragments hybridizing with tRNA are designated. Right: corresponding hybridization patterns with tRNA

with other cloned clDNA segments. This and similar experiments with other cloned fragments (Table 1) showed hybridization to Eco fragments $I, R, S, T$, and $X$, but not to fragments, $J, L$, $\mathrm{M}, \mathrm{O}, \mathrm{P}, \mathrm{U}, \mathrm{V}, \mathrm{W}, 2 \mathrm{~A}$ or $2 \mathrm{~B}$, and $2 \mathrm{C}$. (Eco fragments $\mathrm{M}$ and $\mathrm{O}$ showed some hybridization to contaminating breakdown

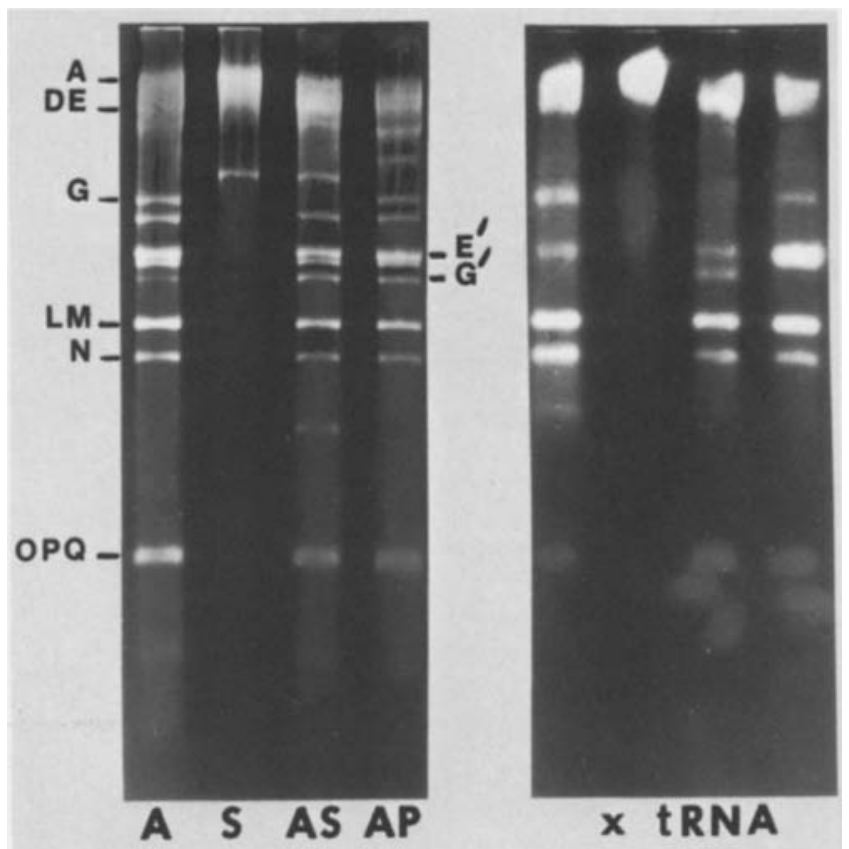

Fig. 8. Chloroplast tRNA hybridization with cIDNA digested by Ava (A), Sal (S), Ava + Sal (AS), or Ava + Pst (AP). Left: Separation of clDNA fragments by agarose gel electrophoresis. Hybridizing Ava fragments are designated. The hybridizing subfragments of Ava $G$ after cleavage by Sal (slot 3) and Ava E after cleavage by Pst (slot 4) are also noted. Right: corresponding hybridization patterns with tRNA

products of rRNA co-purifying with the tRNA if excess unlabelled rRNA was not present during hybridization.)

Hybridization of tRNA to subfragments of the relevant cloned fragments allowed us to determine the positions of the tRNA genes more precisely. Fig. 3 shows the tRNA hybridization patterns to subfragments of Eco segment $R$. The results reveal two regions within $\mathrm{R}$ that hybridize with the tRNA. For example, both HindIII fragments hybridize (slot 4); the two tRNA hybridizing regions are shown in the map in Fig. 4. The RNA hybridized at equivalent positions in each of the three sets of rRNA associated genes. Hybridization in the left region may extend into the Taq fragment with coordinates 355 to 435 . 


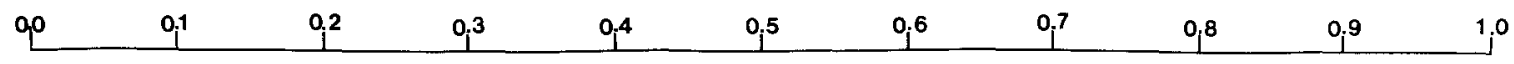

Aval

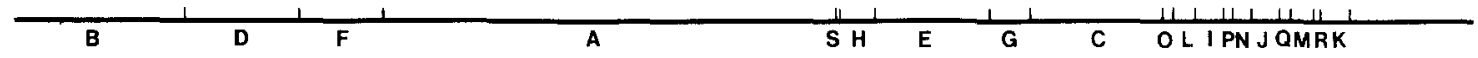

Ball

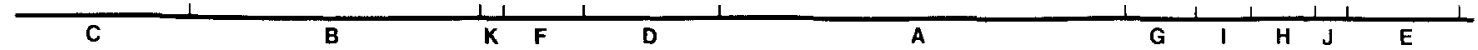

BamHI

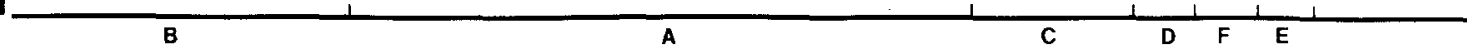

ECoRI

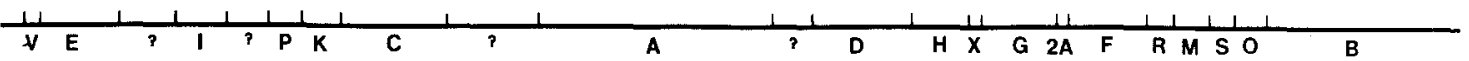

Kpnl

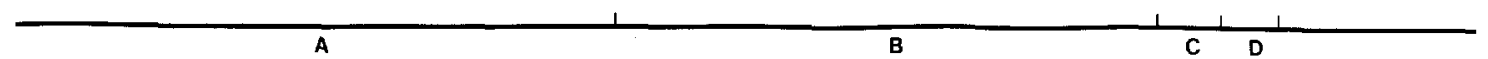

PstI

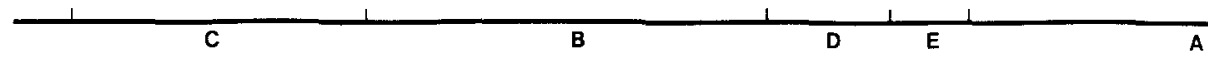

Pvull

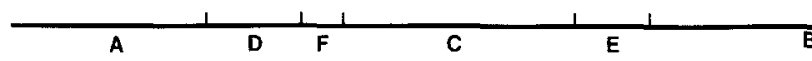

Sall

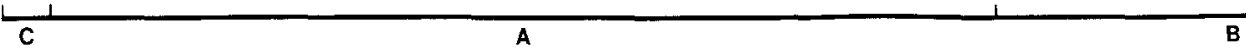

Xhol

A

B

C

Fig. 9. Euglena clDNA restriction site maps for nine endonucleases

No positive result was obtained with this fragment, but the fragment is too small for the result to be meaningful. The tRNA hybridized to the region right of the $\mathrm{Bgl}$ site at coordinate 1955 , but not to the Bgl-Taq fragment from coordinates 1955-2235. Hybridization to the segment right of the Taq site at 2235 was observed to be less intense than to the equivalent Bgl fragment (right of the coordinate 1955), probably because of less efficient binding of the smaller fragment to nitrocellulose.

Less complete restriction site maps showing the positions of tRNA hybridization within other cloned clDNA segments are shown in Fig. 6. Total clDNA digested by each endonuclease separately, and in pairwise combination, was hybridized with tRNA. The RNA hybridized with Eco fragments $A, B, D, G$, I, R, S, T, and X (Fig. 1), consistent with the results with cloned fragments. The tRNA hybridized with the larger of the derivatives of Eco B and G cleavage by Sal (Fig. 1).

The intensity of fluorescence varies reproducibly among hybridizing fragments. These differences may be attributed to nonuniform labelling of different RNA species by radioiodination, variation in concentration of different kinds of RNA molecules, lower efficiency of transfer of large DNA molecules from the gel, and lower efficiency of binding of small DNA fragments to the nitrocellulose filter. The latter two variables are unlikely to be significant for DNA molecules between $8 \mathrm{~kb}$ and $0.5 \mathrm{~kb}$ in size (Southern 1975).

The tRNA hybridized with all of the Xho fragments except the smallest ( $\mathrm{G}$; Fig. 7). However hybridization to Xho F was faint and not always observed. Hybridization was never observed to Ava $\mathrm{H}$, a $0.1 \mathrm{~kb}$-shorter derivative of Xho $\mathrm{F}$ (Fig. 8). As expected, cleavage of Eco B by Xho released a $2.9 \mathrm{~kb}$ fragment containing tRNA genes (Fig. 7); this fragment corresponds to the proximal end of the clockwise-most rDNA repeat (Helling et al. 1979).
The tRNA-hybridizing fragment Ava $G$ is cleaved by Sal to release two segments, the larger containing the hybridizing sequence (Fig. 8). Ava $G$ was cloned, and the restriction map and hybridization pattern of the isolated segment determined. The results show that tRNA hybridizes with a $0.7 \mathrm{~kb}$ portion between a Sal site and a Bgl II site (Fig. 6). The cloned Ava $\mathrm{G}$ fragment was isotopically labelled by nick-translation (Helling et al. 1979), and hybridized to a filter-blot of Eco-digested clDNA. Ava G was observed to hybridize only with Eco fragments $G$ and X (not shown). Therefore Ava G overlaps adjoining Eco fragments $G$ and $X$. The restriction and hybridization patterns of Ava G, Eco G, and Eco X yield the unique orientation of the fragments shown in the overall maps (Figs. 9-11).

\section{Discussion}

We have located precisely the cIDNA restriction sites for nine endonucleases through analysis of single- and double-digest restriction patterns of total cIDNA and of cloned cIDNA segments, and by hybridization studies (Fig. 9, 10). The distance clockwise from the Sal $\mathrm{C}$ site defining the map origin to the first recognition site for each enzyme is given in Table 7 . All of our results are consistent, and we believe this map to be accurate subject to the following qualifications. 1) The orientation of Xho $\mathrm{F}$ with its internal Ava site has not been determined. 2) The Eco fragment between Eco $G$ and Eco $F$ was designated Eco $2 \mathrm{~A}$ because the distance separating Eco $\mathrm{G}$ and Eco $\mathrm{F}$ corresponds approximately to the size of Eco $2 \mathrm{~A}$. However this assignment has not been verified directly. Our results are consistent with and more extensive than current restriction site maps for the $Z$ strain (Hallick et al. 1979). The single striking difference between the $B$ and $Z$ clDNA maps resides in the rDNA. Here the leader sequences of each rDNA repeat differ both among 


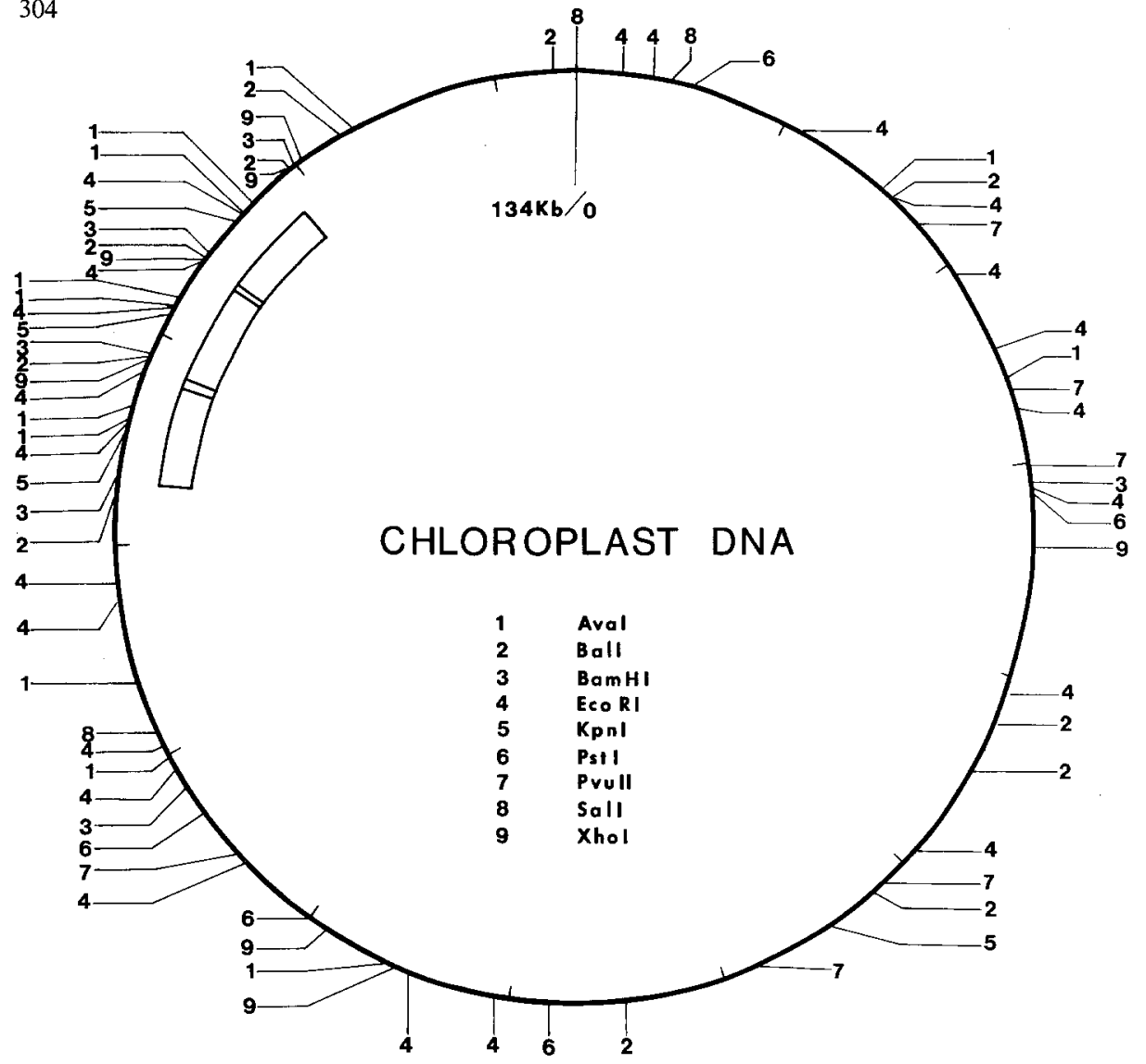

Fig. 10. Euglena clDNA map showing locations of cleavage sites for nine endonucleases, and the three repeated rRNA gene sets. Ava also cuts at all Xho sites (Table 3). Locations of eight of the thirty known Eco sites remain to be identified (see Fig. 9)

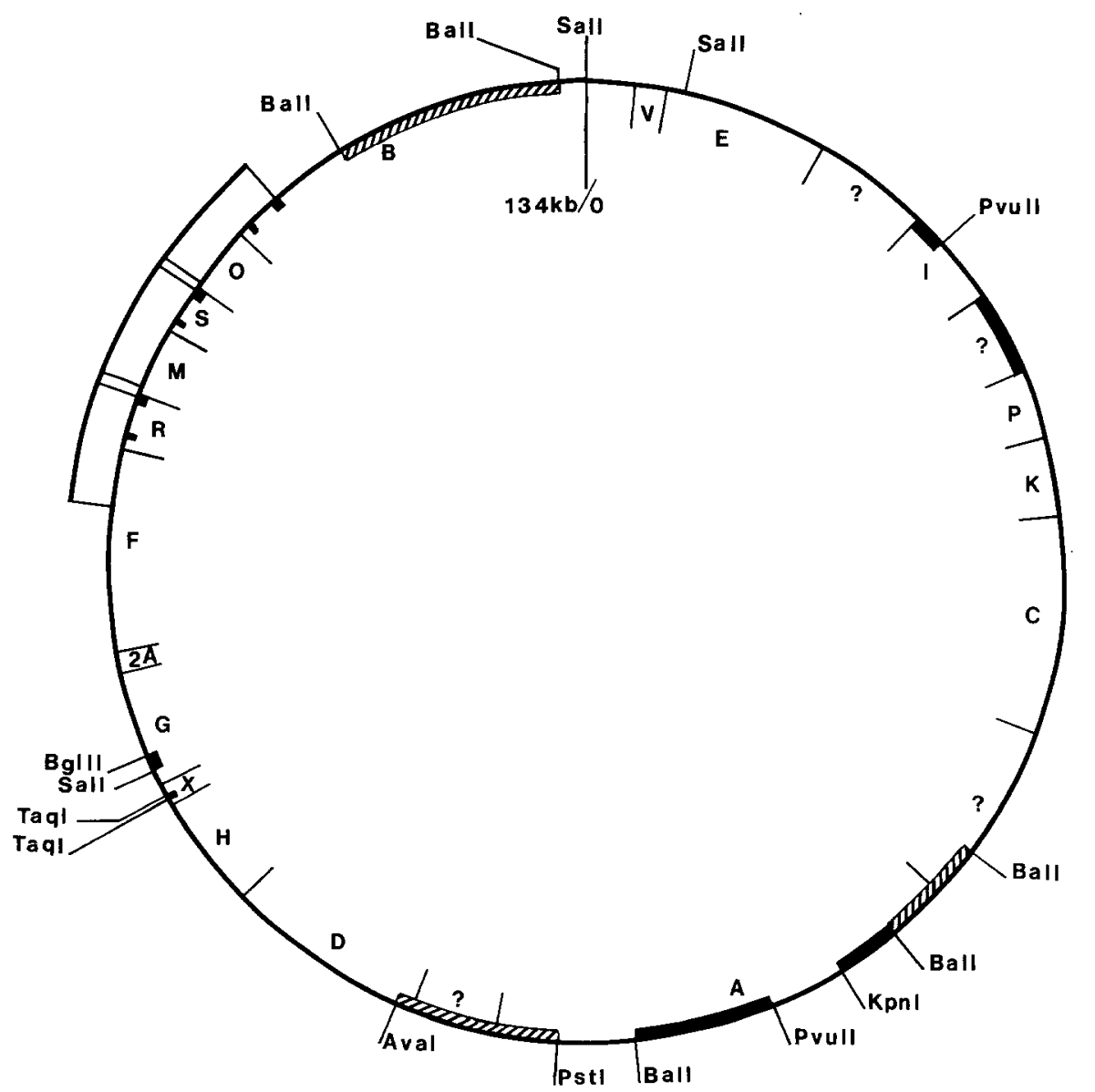

Fig. 11. Euglena cIDNA map showing regions hybridizing with chloroplast tRNA. Solid bars indicate prominent bands of hybridization. Slashed bars indicate regions of less intense hybridization 
Table 7. Position of the first recognition site for each restriction endonuclease

\begin{tabular}{lll}
\hline Enzyme & $\begin{array}{l}\text { Fragment } \\
\text { spanning origin }\end{array}$ & $\begin{array}{l}\text { Distance from } \\
\text { map origin }(\mathrm{kb})\end{array}$ \\
\hline Sal & - & 0 \\
Eco & $\mathrm{B}$ & 2.2 \\
Pst & $\mathrm{A}$ & 5.35 \\
Ava & $\mathrm{B}$ & 15.545 \\
Bal & $\mathrm{C}$ & 16.075 \\
Pvu & $\mathrm{A}$ & 17.825 \\
Bam & $\mathrm{B}$ & 31.015 \\
Xho & $\mathrm{A}$ & 33.935 \\
Kpn & $\mathrm{A}$ & 55.115 \\
\hline
\end{tabular}

themselves and with the equivalent sequences of strain $Z$ (Helling et al. 1979). The three rDNA repeats in strain $B$ and the corresponding regions in strain $Z$ appear to have identical coding sequences for rRNA, so far as we can tell from mapping endonuclease cleavage sites (Fig. 4). Strain $Z$ also has an additional gene for $16 \mathrm{~S}$ rRNA (Jenni and Stutz 1979) that may or may not be present in the B strain.

Our hybridization results with total $t R N A$ reveal a minimum of 15 regions of clDNA containing tRNA genes (Fig. 11). The hybridizing regions correspond well with the more limited mapping reported for the $Z$ strain by Hallick et al. (1979). Euglena chloroplast tRNA yields about thirty RNA spots in two dimensional gel electrophoresis, of which 23 tRNAs corresponding to 18 amino acids have been identified (Mubumbila et al. 1980). Therefore some of the hybridizing regions we have identified must contain genes for more than a single tRNA. Keller et al. (1980) have, in fact, shown directly that tRNAs for both isoleucine and alanine are present between the $16 \mathrm{~S}$ and $23 \mathrm{~S}$ genes of two and probably all three of the complete rRNA gene sets. In addition, a different tRNA (either tRNA $^{\text {Trp }}$ or $t R N A^{\text {Glu}}$ ) hybridizes to the leader sequence of two and probably all four of the $16 \mathrm{~S}$ rRNA genes of strain $Z$ (Keller et al. 1980). The regions of hybridization correspond to those identified by us (Fig. 4), and by Hallick et al. (1979) as hybridizing with total tRNA. Orozko and Hallick (1980) have sequenced the 16S-23S rDNA spacer region and thereby identified directly the genes for tRNA ${ }^{\text {Ala }}$ and $t R N A^{1 l e}$ in the order $16 \mathrm{~S}-\mathrm{tRNA}^{1 \mathrm{le}}-\mathrm{tRNA}^{\mathrm{Ala}}-23 \mathrm{~S}$. Therefore each cIDNA molecule appears to have three copies of each of these genes. If in addition a gene for a third tRNA is present in the leader of each rRNA gene set, a minimum of 17 and probably at least 21 tRNA genes must be elsewhere in the chloroplast genome (Mubumbila et al. 1980).

Acknowledgement. We thank S. Dembinski, M. Ginther, and M. Zorza for their help, and D. Bay for his skilled photography. Supported by NIH grant GM25565, and by the U.S. Energy Research and Development Administration under contract with Union Carbide Corporation. M.R. E-G. is on leave from Alexandria University Science Center for Advancement of Postgraduate Studies.

\section{References}

Adams J, Kinney T, Thompson S, Rubin L, Helling RB (1979) Frequency dependent selection for plasmid-containing cells of Escherichia coli. Genetics 91:627-637

Birky Jr CW (1978) Transmission genetics of mitochondria and chloroplasts. Annu Rev Genet 12:471-512

Denhardt DT (1966) A membrane filter technique for the detection of complementary DNA. Biochem Biophys Res Commun 23:641646
El-Gewely MR, Helling RB (1980) Preparative separation of DNAethidium bromide complexes by zonal density gradient centrifugation. Anal Biochem 102:423-428

Gillespie D, Spiegelman S (1965) A quantitative assay for DNA-RNA hybrids with DNA immobilized on a membrane. J Mol Biol $12: 829-842$

Gray PW, Hallick RB (1978) Physical mapping of the Euglena gracilis chloroplast DNA and ribosomal RNA gene region. Biochemistry $17: 284-289$

Gruol DJ, Haselkorn R (1976) Counting the genes for stable RNA in the nucleus and chloroplasts of Euglena. Biochim Biophys Acta 447:82-95

Hallick, RB, Rushlow KE, Orozco EM, Ir Stiegler GL, Gray PW (1979) Chloroplast DNA of Euglena gracilis. Gene mapping and selective in vitro transcription of the ribosomal RNA region. In: ICN-UCLA Symp Mol Biol 15. New York: Academic Press

Helling RB, Goodman HM, Boyer HW (1974) Analysis of endonuclease R.EcoRI fragments of DNA from lambdoid bacteriophages and other viruses by agarose gel electrophoresis. J Virol 14:12351244

Helling RB, El-Gewely MR, Lomax MI, Baumgartner JE, Schwartzbach SD, Barnett WE (1979) Organization of the chloroplast ribosomal RNA genes of Euglena gracilis bacillaris. Mol Gen. Genet $174: 1-10$

Helling RB, Lomax MI (1978) The molecular cloning of genes - general procedures. In: Chakrabarty A (ed). Genetic engineering CRC Press, W Palm Beach

Jenni B, Stutz E (1979) Analysis of Euglena gracilis chloroplast DNA. Mapping of a DNA sequence complementary to $16 \mathrm{~S}$ rRNA outside of the three rRNA gene sets. FEBS Lett. 102:95-99

Keller M, Burkard G, Bohnert HJ, Mubumbila M, Gordon K, Steinmetz A, Heiser D, Crouse EJ, Weil JH (1980) Transfer RNA genes associated with the $16 \mathrm{~S}$ and 23S rRNA genes of Euglena chloroplast DNA. Biochem Biophy Res Commun 95:47-54

Kopecka H, Crouse EJ, Stutz E (1977) The Euglena gracilis chloroplast genome: analysis by restriction enzymes. Eur J Biochem 72:525-535

Lomax MI, Helling RB, Hecker LI, Schwartzbach SD, Barnett WE (1977) Cloned ribosomal RNA genes from chloroplasts of Euglena gracilis. Science 196:202-205

Manning JE, Richards OC (1972) Isolation and molecular weight of circular chloroplast DNA from Euglena gracilis. Biochim Biophys Acta 259:285-296

McCrea JM, Hershberger CL (1976) Chloroplast DNA codes for transfer RNA. Nucleic Acids Res 3:2005-2018

Mubumbila M, Burkhard G, Keller M, Steinmetz A, Crouse E, Weil JH (1980) Hybridization of bean, spinach, maize and Euglena chloroplast transfer RNAs with homologous and heterologus chloroplast DNAs: an approach to the study of homology between chloroplast tRNAs from various species. Biochim Biophys Acta 609:3139

Orozco EM Jr (1979) Transfer RNA genes of Euglena gracilis chloroplast DNA. Fed Proc 38:820

Orozco EM Jr, Hallick RB (1980) DNA sequence of tRNA ${ }^{\text {ile }}$ and tRNA $^{\text {ala }}$ in the $16 \mathrm{~S}-23 \mathrm{~S}$ spacer region of the IRNA operon of Euglena gracilis. Fed Proc 39:1782

Rawson JRY, Kushner SR, Vapnek D, Alton NK, Boerma CL (1978) Chloroplast ribosomal RNA genes in Euglena gracilis exist as three clustered tandem repeats. Gene 3:191-209

Schwartzbach SD, Hecker LI, Barnett WE (1976) Transcriptional origin of Euglena chloroplast tRNAs. Proc Natl Acad Sci USA $73: 1984-1988$

Slavick NS, Hershberger CL (1975) The kinetic complexity of Euglena gracilis chloroplast DNA. FEBS Lett 52:171-174

Southern EM (1975) Detection of specific sequences among DNA fragments separated by gel electrophoresis. J Mol Biol 98: 503-517

Swanstrom R, Shank PR (1978) X-ray intensifying screens greatly enhance the detection by autoradiography of the radioactive isotopes ${ }^{32} \mathrm{P}$ and ${ }^{125} \mathrm{I}$. Anal Biochem 86:184-192

Communicated by L.S. Lerman

Received January 5, 1981 